\title{
地すべり調査・観測の進展と展望 \\ The progress and the foresight of landslide investigation and observation methods
}

\author{
上野将司 ${ }^{\mathrm{a}) *}$, 中里裕臣 ${ }^{\mathrm{b})}$ \\ Shoji UENO and Hiroomi NAKAZATO
}

\begin{abstract}
This paper describes main challenges and foresights of investigation and observation methods on landslide studies through overview of technological progress in those subjects.

There were much development and introduction of new technology, such as drilling techniques and survey method as LiDAR. However, there still remain inadequate situations in understanding of geological distribution and structure.

As to observation of landslide movement, measurement of the pore water pressure at slip surfaces are indirectly measured by water level in borehole for a long time until present, and it needs more desirable improvement to measure the actual pore water pressure.

Although various kinds of monitoring instruments have been improved and that the observation system has become automatic and convenient, comprehensive observation of the landslide movements on the field is not fully carried.

Active efforts are needed to develop solutions for these issues towards the future. Instrumentation for landslide monitoring is an indispensable technology for implementation of non-structural measures and performance based design of structural measures. Further development is desired towards the future.

Key words : landslide investigation method, landslide observation method

\section{和文要旨}

本論は地すべり調査・観測法について技術の進展を概観した上で, 今後の課題と展望を述べたものである。調査法ではボーリン グ掘進技術をはじめとする技術の発展があり，航空レーザ測量等の新たな技術の導入があった反面，基本的な地質分布や構造把握 が十分になされない状況にある。地すべり動態観測については，長年にわたってすべり面の間隙水圧は孔内水位測定で代用され， 望ましい方法での観測が行われていない。各種観測機器は改良されて観測システムの自動化が進んで便利になったが，現場での地 すべり変動の実態把握がおろそかになってきた。

今後はこれらの問題への積極的な取り組みが必要である。観測機器による地すべりモニタリングはソフト対策や対策工の性能設 計を行う場合に必須の技術であり，今後の更なる発展が望まれる。

キーワード：調査法，観測法
\end{abstract}

\section{1.はじめに}

戦後の荒廃した国土では1947年 5 月の融雪で発生した 新潟県の䅦地地すべりをはじめ, 同県の栃ヶ原地すべり, 長野県茶臼山地すべりなど, 集落や耕地を破壊したいく つかの地すべりの発生で大きな社会問題となった。これ らを契機として地すべり現象の究明や対策工法の開発に 関する気運が高まり，1948年には新潟県が母体になって 各県の技術者の集まりによる全国地すべり対策協議会が 発足した。この組織によって地すべり対策に関する技術 者の交流が盛んになり，横ボーリング工，集水井工，地 すべり抑止杭工等の対策工が開発された。1952年には地 すべり対策事業が国の補助事業として創設され，1958年 の地すべり等防止法の制定により，全国での地すべり調 查・対策が積極的に進められた。その結果，地すべり調 查の一環として，地盤伸縮計，パイプひずみ計，地盤傾 斜計などの観測機器の開発が進んだ。そして1963年には 地すべり学会が設立され, 研究者と技術者が一堂に会す る場が生まれた。

\section{* 連絡著者/corresponding author}

）応用地質株式会社エンジニアリング本部

OYO Corporation Engineering Headquarter

テ331-8688ささたま市北区土呂町2-61-5

b ) 独立行政法人 農業・食品産業技術総合研究機構 農村工学研究所

National Institute for Rural Engineering
1970年，当時の国鉄飯山線で発生した高場山地すべり では地すべり崩壊時期が地盤伸縮計の観測記録をもとに 予知されるという画期的な出来事があった（山田ほか, 1971)。この崩壊予知の成功により, 地盤伸縮計は崩壊 時期の予知手法としての斎藤の方法 (斎藤，1972) とセッ トで地表面変動の観測機器の中心になっていった。一方, 地中のすべり面を検出するためにパイプひずみ計が普及 し，やや遅れて1975年に米国から精度の良い孔内傾斜計 が導入され普及した。また，地下水流動を調査するため の地下水検層法の開発普及, 調査手法として物理探査の 適用が積極的になされ，リングせん断試験など特殊な室 内試験の導入と発展があった。

この後は経済成長期の新幹線や高速道路の整備, 大夕゙ ムの建設に伴う切土，トンネル掘削，貯水等の影響によ る人為的な地すべりの発生，居住圈が丘陵地や山麓に及 ぶことによる地すべり被害が目立つようになった。1985 年に長野市の住宅地で発生した地附山地すべりでは26名 の人命が失われ，この災害を契機として民間各社の手で 各種の地すべり自動観測システムが開発され実用化が進 んだ。更には通信網の発達により，膨大なデー夕を居な がらにして入手できるようになり，緊急時の判断などが 円滑に行われるようになった。

以上のように，地すべりの調査・観測は実務を通じて 
発展してきたものであり，以下には具体的な調査・観測 法の進展, および課題と展望についてやや詳しく見てい きたい。

\section{2. 調査法の進展}

\section{1 予備調査}

既往の調查資料 - 文献 - 地形図 - 地質図 · 空中写真判 読結果・航空レーザ測量データ・災害記録等を収集整理 すると, 対象地域の地すべり地形・崩壊地・地質分布・ 断層破砕带・崩積土の分布等, 様々な情報を得ることが できる。とくに空中写真判読や航空レーザ測量は，地す ベり調查をはじめ斜面変動調查に有効であり, これらを 利用する現地踏查を含めて調查法の進展について述べる。

\section{空中写真判読}

わが国に扔ける空中写真による地形判読の先がけは戦 前の1930年の中央気象台による北伊豆地震での断層調査 や鉄道省による路線選定調查で実施された（日本応用地 質学会, 2006)。戦後になると米軍撮影の空中写真を使 用して戦後復興事業，資源開発，災害調査が行われてい る。1961年 6 月の天竜川流域の崩壊・土石流災害に対し, わが国初の広域災害調査を目的にした空中写真撮影が実 施された（大八木，1986)。ここでの空中写真判読は崩 壊地形等の効率的な調査に有効であった。また，1962年 には四国山地を横断する土讃線の土砂災害対策で防災対 策委員会が組織され空中写真判読が行われるなど，空中 写真判読は災害調查等の基礎調查手段となった。

その後しばらくして, 多くの事例に基づいた崩壊や地 すべりに関する空中写真判読法（建設省国土地理院, 1976）が出版され技術者にとって良い指針になった。ま た「日本の活断層」(活断層研究会, 1980) の出版により, 空中写真判読は活断層などの変動地形の抽出に有効であ ることが示された。これらの結果, 空中写真判読の重要 性が認識され各種予備調查の一環に組み込まれるように なった。

一方，独防災科学技術研究所では，地すべり研究者が 国内の地すべり地形を空中写真判読によって抽出した結 果を 5 万分の一地形図に表現した地すべり地形分布図の 作成が1982年以降（たとえば清水ほか，1982）長期的に 継続して進められている。この結果はウエブサイトに公 開 (http://lsweb1.ess.bosai.go.jp/) されて多くの研究 者や技術者に利用されるようになった。

また，少し古い撮影写真になるが全国を対象にした空 中写真が国土交通省国土政策局から公開 $(\mathrm{http}: / / \mathrm{w} 3$ land.mlit.go.jp/) されており, いつでも簡単に無償で画 像をダウンロードでき，緊急調査などに役立っている。

\section{航空レーザ測量}

斜面の調査に大きな影響を与えつつあるのは航空レー ザ測量の登場であろう。航空レーザ測量により取得され る地形情報量の飛躍的向上は, これまでの大縮尺地形図 で表現できなかった微地形を浮きださせることが可能に
なった。具体的には，小規模な二重山稜，小崖，凹地， 斜面の微細な緩急，さらにはクラック，転石などが地形 図に表現できるようになり，大規模な崩壊の兆候を示す 微地形の把握も可能になりつつあって, 空中写真判読以 上の成果が得られる場合がでてきた。地形判読をし易く するような工夫の研究も進んでいる（千葉ほか，2007）。

\section{現地踏查}

地すべりの現地踏查では滑落崖, クラック, 湧水, 家 屋や構造物の変状など, 地すべり変動に伴う現象の調査 が行われてきたが，これらを参考にした地すべりブロッ クの決定根拠が不明な調查例が散見される。また，大縮 尺の地形図の整備や精度が十分ではないことや地すべり 地では露頭が少ないことに起因すると思われるが，地質 分布や構造が把握されていない事例が多いように思う。

実務的な調查では多くの場合, 風化带区分をもって地 質断面図とし，対応する地質平面図のない状態が続いて きた。地すべり断面はすべり面の明示や風化区分が必要 ではあるが地質構造がわかる表現であることが望ましい。 平面図も同様で地すべり変状に基づく地すべり範囲とと もに地質平面図を示すべきである。地すべりと地質構造 との関係が明らかになると地すべりの素因を読み解くこ とができるので，地質情報を表現することは重要な問題 である。

一方，地すべり現地踏查を行う際に，航空レーザ浿量 による地形図の整備がある場合には微地形が表現されて いるので地すべり変状に関しては見落としの無い効率的 な調査が可能になった。また, ハンデイタイプの測距器, GPS, 高度計等が導入されて位置精度の高いマッピング が行われるようになった。

\section{2 本調查}

一般的な地すべり調查で適用されることの多い手法で あるボーリング調査, 物理探査および検層, 地下水検層, 室内力学試験について進展を述べる。

\section{ボーリング調査}

地すべり地におけるボーリング調査はコア採取技術の 未熟な時代が長く続き，場所によってはコア採取率が $30 \%$ 以下のわずかな状態での地質断面作成を強いられて きた。しかし，1980年代になるとボーリングコア採取技 術の開発が進み, 三重管式のコアパックチューブの導入 や循環水の替りに気泡を使うことによってコア採取率が 劇的に向上した。地すべりや破砕带のような地質状況の 劣悪な部分でも $100 \%$ のコア採取が可能になり，地質観 察の精度が格段に向上した。これにより，すべり面位置 を地質面から詳しく観察して検討できるようになった。

ボーリング調査は予備調査を経て, ある程度の地すべ り全体像を把握した上で配置や深度を計画して着手し， 掘進状況や採取コアと地質構造を総合的に考慮しつつ調 查を進めれば大きな問題は生じない。しかし，ボーリン グの採取コア観察のみの判断で調查を打ち切ると, すべ り面まで到達しないような無駄な調查になることがある 
ので調査の取り組み姿勢には注意すべきである。

\section{物理探査および検層}

ボーリング調査は既に述べたようにコア採取技術が未 熟であり，地すべり地ではコア採取率が悪く地質観察が 困難な場合が多かった。このため地すべり調查ではボー リング調查に対して経済的で効率的な地表からの物理探 查やボーリング孔を利用した物理検層が1960年代は各地 で盛んに適用された。とくに電気検層は, 測定結果で得 られる比抵抗值がボーリング柱状図や地すべり地の地質 断面を作成するより所になり，多くの現場で採用された。

弾性波探查は玉城ほか（1966）による大阪府亀の瀬地 すべりでの適用や，小林ほか（1979）による徳島県正夫 地すべりでの適用に始まる。また電気探查については田 治米ほか（1964）の予察的な適用や，竹内（1970）によ る高知県下の地すべりに対する本格的な調査があげられ る。当時の地すべり対策は, 排水対策工が主体であった ため, 物理探査による地すべり断面形状の概略把握でも 一応の目的を達していた。

ところが, 地すべりの対策工種に品質の良い杭，アン カー等の抑止工が開発され, 積極的に施工されるように なると, 地すべり断面形状について精度の良い成果が求 められることになった。一方ではボーリングコアの採取 技術の向上，パイプひずみ計を主体とする計測技術の積 極的な導入などによるすべり面の想定精度の向上があっ た。このため, 物理探査主体の調査は目的を達成できな くなり1980年代になると衰退した。その後, 物理探查お よび検層はコンピュータ技術の発達に伴うトモグラ フィー解析技術の進歩により解析精度が向上（例えば島 ほか，1995）し，再び地すべり調查での適用事例が増加 して復活することになった。とくに大規模な地すべり調 查ではボーリング調查の補助手段として効果的に適用さ れ成果をあげている。

\section{地下水検層}

ボーリング孔を利用して地すべり地の地下水流動層を 検出しょうとする画期的な研究は 1960 年代に当時の建設 省土木研究所地すべり研究室で取り組まれた。ボーリン グ孔内に食塩を溶解させた後，一定間隔の電極をボーリ ング孔内に設置して周辺地下水の流入による孔内食塩水 の希釈状況を比抵抗の増大する変化でとらえようとする 方法である。渡ら（1965）により室内実験, 現場実験が 行われ, 地下水検層法と命名されて測定器が製品化され, 地すべり地における地下水調査の標準的なメニューとし て急速に普及した。

この測定法は通常数時間に及ぶ測定時間，電極を孔内 に静置して比抵抗変化を測定するものであったが, 装置 の持ち運びや取り扱いの面で不便であったため，1970年 代後半には携帯型電導度計を孔内で移動して測定する方 法が登場した。榎田ら（2010）によれば，孔内を測定器 が移動する方法は孔内水の攪找の影響が大きく測定值の 精度にも問題があったため, 1985年頃に測定器の形状等
に改良が加えられて現在用いられている信頼性の高い移 動式（懸走式）の地下水検層器が完成したとされている。

\section{室内力学試験}

地すべりの安定計算に用いるすべり面のせん断強度に ついては，1970年代まで乱さない試料の採取が困難で あったことに加えて，すべり面のせん断強度を求めるた めの力学試験法が確立されていなかった。乱さない試料 を苦労して採取して力学試験を行ってもせん断強度が大 きな值（ピーク強度）になり，地すべり斜面の妥当な安 全率を求めることができなかった。このため，実務では 地すべりの移動状況を参考にして安全率を $\mathrm{Fs}=0.98$ な どに仮定して，いわゆる逆算法によってすべり面のせん 断強度を求めることが行われるようになった。

一方，1977年に第 9 回国際土質基礎工学会議が東京で 開催され，Skempton（1977）による特別講演により斜 面の長期安定には残留強度の概念が必要であることが国 内に広く知られることになった。残留強度を求めるため の試験法として, 繰り返し一面せん断試験やリングせん 断試験法が考案されており，中村ら（1978）は国内にリ ングせん断試験機を導入して地すべり粘土に対する試験 に精力的に取り組んだ。これを契機として，すべり面の せん断強度に関する研究が進み, ピーク強度, 軟化強度, 残留強度といった有効応力パラメー夕を求めるための試 験法が整備されてきた。すべり面の軟化強度や残留強度 を求めるためのリングせん断試験や繰り返し一面せん断 試験法の供試体は, 乱した試料を調整すればいいので試 料採取が容易になり, 実務でも積極的に力学試験を行う 傾向になってきた。

\section{3. 観測法の進展}

地すべり変動の観測に用いられる計測機器は, 地表変 動計測, 地中変動計測, 地下水観測に大きく 3 区分され る。以下，この区分によって主な観測法の進展について 述べる。

\section{1 地表変動観測}

地すべりの移動特性, 移動範囲を把握する上で, 地表 変動観測は最も基本的な調查項目であり, 移動速度に応 じて抜き板による観測や移動杭測量が行われてきた。さ らに移動機構に迫るためには降雨, 融雪等の誘因に対す る移動量応答を把握する必要があり, 各種計器観測によ る連続的な観測が行われてきた。

\section{地盤伸縮計}

昭和 30 年代後半には現在広く普及しているペンドラム 式の地盤伸縮計が製品化され普及した。地盤伸縮計は, 地表面の亀裂や滑落崖をはさむ 2 点間に温度の影響を受 けにくいインバー線を張って記録器でその伸縮変化を測 定する。記録器ではゼンマイ式の巻き取りドラムに記録 紙を巻きつけてペン書きで記録をとる機器が今日でも用 いられている。遠隔での自記記録が可能な測定器はドラ ムの回転をポテンシオメータで電気的に検出する方式に 
よっており，観測システム次第では携帯電話等で監視で きるものが普及している。

前述のように1970年 1 月，当時の国鉄飯山線高場山地 すべりにおいて，地盤伸縮計の変位記録に基づく崩壊時 期の予測が的中したことがあり，地盤伸縮計は情報化施 工や道路・鉄道等の防災上の維持管理ツールとして積極 的に導入されてきた。

\section{地盤傾斜計}

地盤や構造物の傾斜変動を観測する目的で昭和30年代 から水管式の測定器が製品化され普及した。高精度の水 準器であり，しっかりしたコンクリート基礎の上にガラ ス板を置き，この上に水準器 2 台を直交方向に設置し， 直射日光や降雨等の影響を避けるため木製の箱などで保 護する。

この測定器は自記記録を行うには不便であるため，振 り子を用いて電気的に傾斜変動を検出するセンサーが普 及した。ただし，このセンサーは温度変化の影響を受け やすいため，気温の影響を極力受けないような設置の工 夫が必要である。

地盤傾斜計は変動が確認された場合，局所的な変動と 広がりを持った不安定斜面の変動との区別がつきにくい ことがあるため，近年ではGPSに取って代わられつつあ る。

\section{GPS}

GPSによる移動量観測は，不動地に設置した基準点と 地すべりブロック内に設置した移動点においてGPS衛星 からの信号を同時に受信し，搬送波位相を利用する干渉 測位により移動点のcmオーダーの座標変化を求める手
法である。地すべり分野では1980年代から試験的に導入 され，地すべり学会では1990年の研究発表会において最 初の研究発表が行われた（福岡ほか，1990）。最近では 国土交通省，農林水産省の調査指針や計画基準において 地表移動計測手法の一つとして位置づけられており， GPSの精度向上と急速な普及による機器の低価格化が あって，大規模な地すべり斜面の変動計測等に固定設置 して連続観測を行う事例が増えている。現状では天空視 界の関係で設置できない場所，測位誤差等の問題がある が，観測点間の視通を要さない，移動方向・移動量の制 限がない利点は他の地表変動観測手法に無い特徴であり, 斜面の変位計測用の機器として発展している。図 - 1 は 2009年 2 月から 7 月にかけて幅 $400 \mathrm{~m}$ ，長さ $700 \mathrm{~m}$ の範囲 が最大 $6 \mathrm{~m}$ 以上滑動した山形県七五三掛地すべりにおけ るGPS観測の事例である（中里ほか，2009）。ここでは $5 \mathrm{~km}$ 離れた電子基準点を固定点として,1周波型受信器 による 6 時間セッション毎の連続自動観測を行うシステ ムを構築した。 4 月〜 5 月には降雨後遅れて移動速度が 増大する傾向や，ディープウェルによる地下水強制排除 の開始に伴い移動が沈静化する様子がとらえられた。

\section{2 地中変動観測}

\section{パイプひずみ計}

地すべり対策ではすべり面深度を明らかにすることを 目的として，各種の測定管が考案されたが，新潟県技師 であった湊元光春博士を中心に1958年頃に塩化ビニール パイプにひずみゲージを貼り付けたパイプひずみ計が開 発され，1962年までには新潟県杤ヶ原地すべりでボーリ ング孔に設置され観測が行われた（日本地すべり学会新

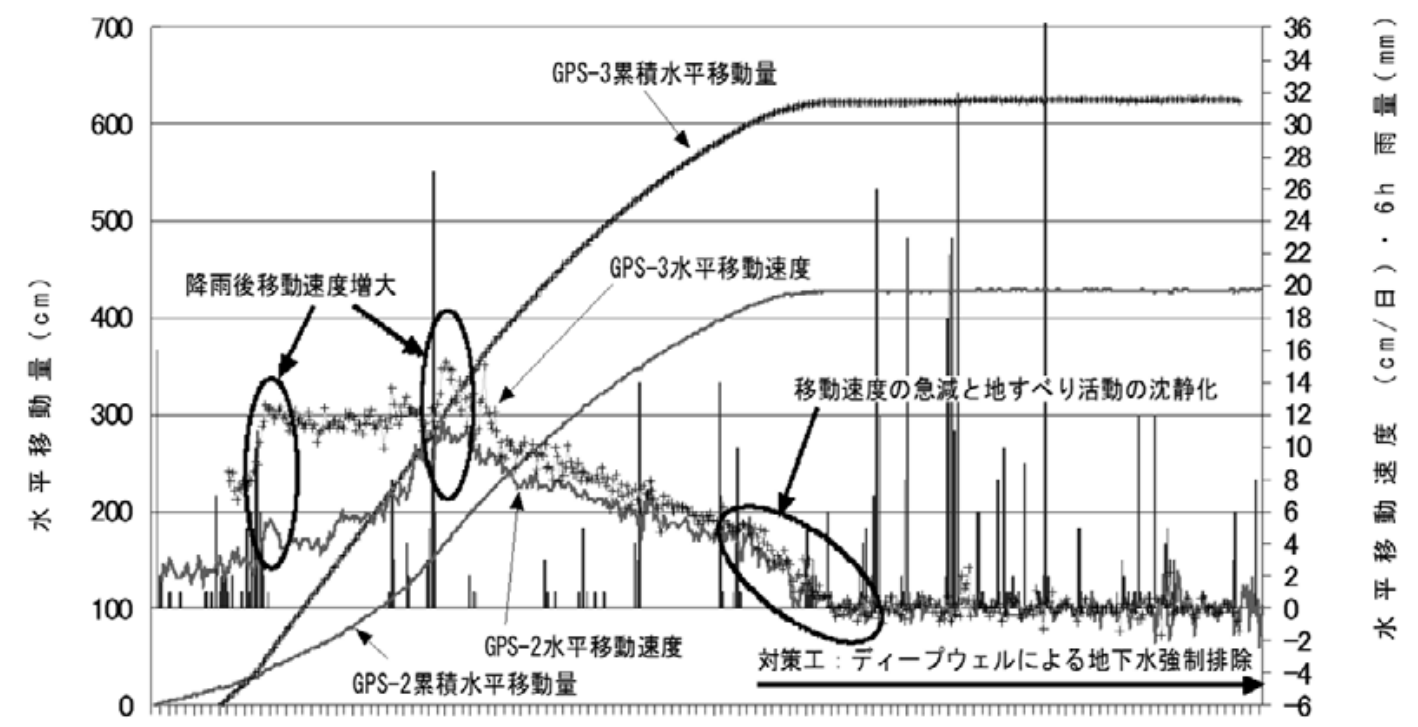

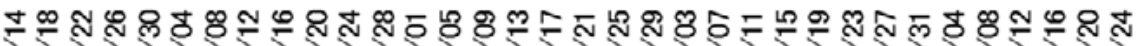

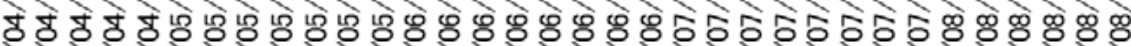

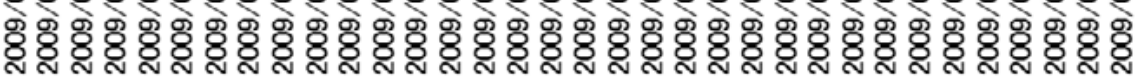

図ー1ＧPSによる地すべり変位の計測結果

Fig. 1 Observation result of the landslide displacement by GPS 
潟支部，2008)。当時のパイプひずみ計は現場で塩化ビ ニールパイプにひずみゲージを貼り付けて防水シール加 工していたため，測定結果の信頼性や耐久性に問題が あった。その後, 多くの現場で適用される中で1960年代 後半には製品化されて品質が向上し，地すべり調查の標 準的な仕様として組み込まれて急速に普及した。この背 景には同時期に開発されていた孔内傾斜計の精度が満足 できるものではないこともあった。

標準的なパイプひずみ計は径 1.5 インチ塩化ビニール パイプにひずみゲージを 2 枚一対にして張り付けたもの である。これを通常は $1 \mathrm{~m}$ 間隔でボーリング孔内に挿入 設置し，間詰めを行って周辺地盤と一体化させる。す心゙ り面変位があればパイプが変形してひずみゲージに生じ たひずみを電気抵抗変化として計測するものであり， データ収録の自動化が容易で密な測定が可能など扱いや すい特徴がある。

ひずみゲージの間隔については中村ら（1976）の研究 があり，薄いすべり面の場合は塩化ビニールパイプが短 い区間で屈曲するために $0.5 \mathrm{~m}$ 以下の間隔にしないとひ ずみを検出できない場合があるとされており岩盤すべり などでは注意を要する。

パイプひずみ計の観測結果から地中のパイプの変形を 求める方法が山口（1972）によって示されているが，ひ ずみからパイプの傾斜および変形を求めることになるた め通常の設置方法では大きな誤差を生じる。パイプひず
み計とボーリング孔壁との間詰めをグラウトなどで完全 に行うとともに，すべり面付近でのひずみゲージの間隔 を密に設置すれば地中のパイプの変形を求めることがで きる。

\section{孔内傾斜計}

終戦直後から地すべり調査に取り組んだ福岡正巳博士 は，すべり面測定器として振り子式（重錘式）の傾斜計 を開発した。この傾斜計はあらかじめすべり面に設置し て計測するタイプの設置型であったため，設置深度の誤 りによるすべり面の見逃しが多かったようである（山口 ほか，1964）。

この久点を補うため，回転式傾斜計と呼ばれる挿入式 の孔内傾斜計が開発された。これは傾斜計の振り子の柄 を板バネとしてひずみゲージを貼付し，電気抵抗で傾斜 を検出するものである。最大傾斜を求めるために傾斜計 を回転しつつ孔内に挿入し，任意の深度で最大傾斜と方 位の測定が可能であった。1963年に国鉄山陰本線の地す べり調査で適用（山田ほか，1971）されるなど各地で使 用されたが，傾斜の精度が約 20 分であったため大変位で ないと検出は困難であった。その後，傾斜計プローブの 挿入方向を決めて測定する今日見られる孔内傾斜計が開 発されたが，傾斜計センサーの分解能が十分ではなく地 すべり変位を検出する点においてパイプひずみ計よりも 劣っていた。

1975年になってセンサーにサーボ加速度計を用いた米

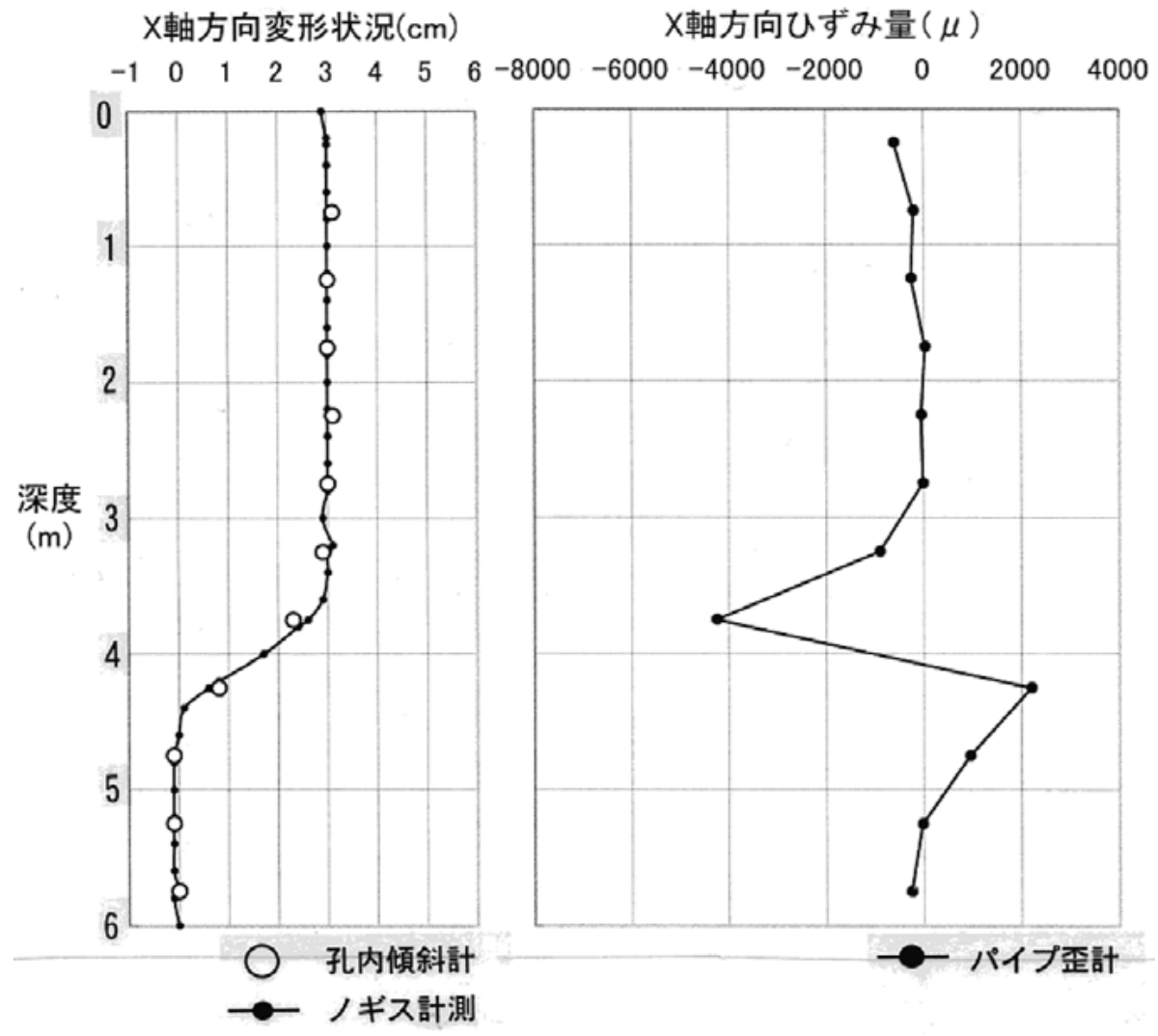

図一2 孔内傾斜計とパイプひずみ計の測定結果の比較

Fig. 2 Comparison of the observation result of inclinometer and strain gauge pipe 
国SINCO社製の高精度孔内傾斜計が導入された。この 傾斜計によって地すべりによるガイドケーシングの変形 が精度よく測定できるようになり，パイプひずみ計との 直接的な比較実験（大矢，1977）が行われた。実験に用 いたガイドケーシングは延長 $6 \mathrm{~m}$ のBS樹脂製で，傾斜 計測定用の溝方向に一致させて $50 \mathrm{~cm}$ 間隔で 2 方向 4 ゲージの歪み計を貼付している。このガイドケーシング を鉛直に固定して種々の変形を与え，実際の変形につい て下げ振り線を基準としてノギスで実測し，これと傾斜 計およびパイプ歪み計による測定值を比較したものであ る。実験結果の一部は図-2 に示すとおりで, 孔内傾斜 計の精度はパイプ歪み計と同等であると結論づけている。

孔内傾斜計の測定結果から地中に設置されたガイド ケーシングの変形状況が容易に可視化できるようになり, すべり面の調查手段として急速に普及した。今日では同 程度の精度を持つ各種センサーの孔内傾斜計が製品化さ れ，パイプひずみ計とともにすべり面調查に適用されて いる。

\section{地中伸縮計}

地中伸縮計は，ワイヤの一端を基盤中に固定し，地す べりの移動によるワイヤの地中への引き込み量を地表に 設置した伸縮計で計測するもので，ワイヤの切断がない 限りパイプ歪み計や孔内傾斜計よりも長期的かつ大変位 の観測が可能とされている。ワイヤの固定部を複数深度 に設置することにより区間別の変位量を計測し，複数す べり面観測にも対応するものは多層移動量計と呼ばれて いる（社団法人地すべり対策技術協会，1996）。地中伸 縮計では設置直後のワイヤのたるみや保孔管とのクリア ランスにより，ある程度地すべり変位が進まないと計測 が開始されない初期無感带があるとされる。このため孔 内傾斜計と地中伸縮計を併設したり，孔内傾斜計が観測 不能になる頃に地中伸縮計を設置するなど，個々の観測 手法の特徵を活かした工夫が行われている。地すべり移 動層が剛な場合は，すべり面における移動量がワイヤの 引き込み量に等しくなることが期待されるが，一般に地 中伸縮計や多層移動量計で観測される変位量が地表変位 量より小さいことや，逆方向の圧縮変位がしばしば観測 されることが知られている。これらの現象は，主に移動 土塊内のクリープ変形によることが指摘されている（平 元ほか, 2008)。

\section{3 地下水観測}

地すべりの誘因が降雨や融雪であることが経験的に知 られていたため, 終戦直後に発生した新潟県の柵口，神 谷，栃ヶ原などの地すべりでは地下水調查や排水対策が 行われた。高野（1960）は上記の新潟県における地すべ りの調査や対策の経験をもとに，地すべり変動と降雨や 地下水との関係を示し，排水対策が有効であることを述 べている。地すべりの排水対策が効果的であることは, すべり面に作用する間隙水圧を考慮した有効応力法によ る安定解析により説明できる。安定解析に関して有効応
力法の適用がオーソライズされたのは1961年の第 5 回国 際土質基礎工学会議とされ（斎藤，1976），国内でもす ベり面の間隙水圧を測定しょうとする動きが見られるよ うになる。

岸本（1967）は長野県の新第三紀層地すべり現場にお いて，4箇所に間隙水圧計を設置するとともに，5箇所 の地下水位観測孔を設置して降雨と間隙水圧の関倸を詳 細に検討している。この地下水位観測孔については内径 $28 \mathrm{~mm}$ の細い塩化ビニール管を使用し，ストレーナ区間 を $50 \mathrm{~cm}$ に限定するなど，間隙水圧に近い水位変動を得 ようとする工夫がなされている。

この後もピエゾメータ式の間隙水圧測定や電気式の間 隙水圧計を埋設して観測を行う事例が多かったが，すべ り面付近に設置する必要があることやメンテナンスが困 難であることから次第に衰退していった。一方ではパイ プひずみ計等の設置孔を利用して孔内水位が計測できる ため，すべり面の間隙水圧測定は孔内水位測定に置き換 えられていった。孔内水位の測定は手計測やフロート式 のペン書き自記記録式測定器が用いられたが，フロート やワイヤーが孔壁との摩擦で水位変化に追随せず観測結 果が得られない場合が多かった。このため1980年代後半 になると，地すべり地での自動観測システム化が進めら れたこともあって，孔内水位観測には水圧式水位計を用 いることが一般的になり現在に至っている。

ただし，孔内水位観測孔の保孔管には設置の容易さな どから，塩化ビニールパイプの全長をストレーナ加工し た材料が用いられている。このような観測孔では帯水層 が複数ある場合は複合的な水位をとらえてしまい，正確 なすべり面の間隙水圧を測ることが出来ない。すべり面 の間隙水圧を正しく測定するためには，先に述べた岸本 が40年以上前に採用した部分ストレーナ方式の様に透水 区間を限定した小口径の観測孔でなければならない。

\section{4. 調査法の課題と展望}

\section{1 予備調查}

\section{地質踏査技術}

地すべり調査の平面図や断面図に地質分布および構造 が示されていない場合，地すべり機構の地質的な素因を 検討することができない。三次元的なすべり面形状が地 質平面図や地質断面図に表現されるべきであるが，実務 の調查報告書ではそうなっていないものが多い。地質図 の作成は重要な問題であるにも倸わらず作成されないの は次の様な理由による。

(1) 地質図作成の重要性が地すべり調査において十分 に理解されていない。

(2) 一般に踏查範囲は地すべり地付近に限定されて地 質観察のできる露頭が限られ，情報の不足により 地質分布や構造が明らかにできない。

(3) 地質が複雑な分布や構造を示す地域では地質技術 者でさえも地質図作成が困難な場合がある。 
(4) 地質踏査技術の伝承が難しく地質技術者が育成さ れていない（横山，2007）。

これらのうち(4)の地質踏査技術者の育成が深刻な問題 であり，技術者を育成しても(3)のうな地域がある。大 学での地質踏査教育が困難な状況にあることや，企業内 での技術の伝承が十分ではないことから質の良い地質踏 査の出来る技術者は減っている。解析技術などが進展し ても地道な踏査が不足であれば，砂上の楼閣のような対 策に結びつきかねない。上記(1)，(2)の問題については学 会が中心になって産官学の連携を図り，地質図作成の重 要性を訴えるなどの働きかけを行い，そのような環境の 中で(4)の地質技術者の育成を図るべきで，(3)はその先に ある問題である。

\section{空中写真判読}

空中写真判読は，予備調査段階では活用されているが, 本格的な調査に入ると顧みられなくなる傾向にある。踏 査結果，ボーリング調査結果，地すべり観測結果等の情 報を考慮した上で，改めて判読すると地すべり範囲の確 定やブロック区分などに役立つ。ただし，同じ空中写真 を対象にした場合でも専門技術者間での相違があり，判 読対象や結果の表現法などが統一されていない。これら の課題の解決に関して応用地質学会での取り組みがあり, 特に斜面変動について同一対象に対し複数の専門技術者 による異なる判読事例が多数まとめられていて参考にな る（日本応用地質学会，2006）。今後は空中写真を反復 して判読することや，判読対象と表現の統一が望まれる ところである。

\section{航空レーザ測量}

航空レーザ測量は，精緻な微地形を可視化し，立体画 像や各種の地形解析を容易にするなど技術開発が急速に
進んでいる。取得データから樹木の高さを計測して森林 管理に利用するなどの応用面での取り組みも広がってい る。最近では航空レーザ測量を異なる時期に行うことに よって，計測手段として地すべり変動を捉えることや， 崩壊，土石流による地形変化を明らかにすることに利用 され始めており，地震前後の精緻で面的な斜面変動を捉 えた例が報告されている（向山，2010）。このような点 からも航空レーザ測量の地形取得技術は今後の更なる精 度の向上が期待される。

\section{2 本調查}

ボーリング調査

ボーリングコアの採取技術の進歩によって劣悪な地質 でも100\%のコア採取ができるようになり地質情報が補 強された。その一方で技術者のボーリング掘進技術に関 する理解不足があって掘進時の情報が柱状図に上手く整 理されていない。一因として技術者が掘進作業に長時間 立ち会わない状況があるので改善を促したい。この点と あわせて地すべり調査に特化した柱状図の様式があるの でこの十分な活用を図るべきである。とくに，掘進期間 中の孔内水位は毎日の作業前後に測って掘進水頭図に整 理し，逸水や湧水に関する情報を得る努力が必要である。

\section{物理探査および検層}

地すべり調査では個々の地すべりに対する詳細調查と して弾性波探査と電気探査が適用されてきた。これに対 し，概査段階で地下の情報を非接触で広範囲に得る手法 として空中電磁探査の適用がある。ヘリコプターによる 電磁探査によって，空中から地下の比抵抗構造を間接的 に探査する方法である。ここ数年，鈴木ら（2009）によ る取り組みに代表されるように，山地部での大規模な不 安定斜面を抽出することが試みられている。広域の地す

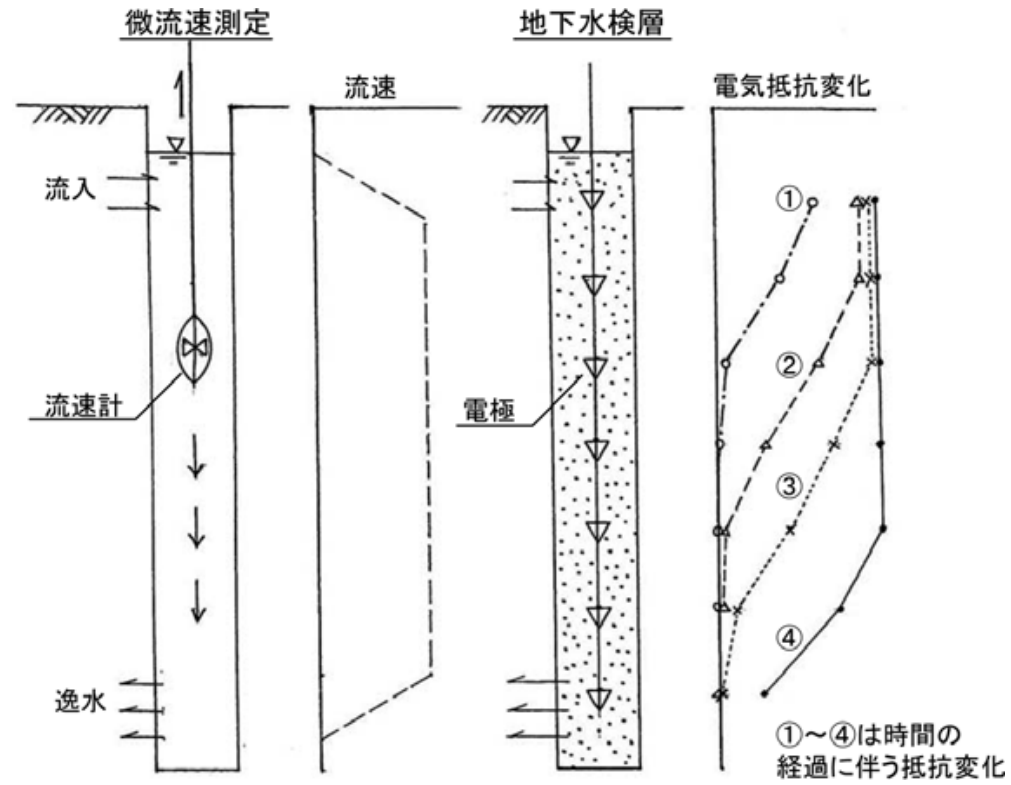

図-3 微流速測定と地下水検層の測定模式図

Fig. 3 Measurement comparison of the water flow in borehole with Micro-flow meter and a groundwater logging machine (model diagram) 
ベり調査も行われており，今後は解析結果と地上調查と の対応を検証するなど，実績を積み上げて精度の向上を 目指す段階にある。

ボーリング孔を利用する物理検層については，良質の ボーリングコア試料が採取できるようになって適用され ることが少なくなったが，すべり面判定をコア観察だけ に頼らず定量的な指標を加えて判断する動きが出てきた。 山崎ら（2001）はコア観察に加えて反射検層を適用して 客観的なすべり面の決定法について報告しており，今後 の物理検層の活用が期待される。

\section{地下水検層}

地下水検層は透水層を検出するための優れた調査法で あるが，孔内水がない場合に試験ができないこと，試験 条件を工夫して行わないと透水層の検出が困難な場合が ある点に注意を要する。同様な方法として温度検層（竹 内，1996）があり，孔内水が無い場合でも透水層の検出 が可能である。孔内水がある場合は地下水検層と同様で 透水層の検出が難しい場合がある。

これらの問題に対処する手法として孔内微流速測定が あり，地すべり調査で適用（上野，2000）されているが, 測定器が普及していないので一般的な調査手法になって いない。この方法は直径 $42 \mathrm{~mm}$ の流速計をボーリング孔 に挿入して孔内水の鉛直方向の流速を深度ごとに測定す るもので, 孔内水が無い場合でも注水条件での試験に よって透水層の検出が可能である。また，水位条件を注 水や揚水によって変化させることで，透水層を見逃すこ となく透水係数や水頭を求めることができる。

しばしば遭遇する例として水圧の異なる上下 2 層の透 水層を貫いたボーリング孔での地下水の流れについて説 明する（図-3）。上部透水層の水圧が高ければ，上部 層から孔内へ地下水が流入し，孔内を下向きに流れて下 部透水層で逸水する流動が発生する。地下水検層では孔 内を食塩水で満たし電気抵抗の変化を測定する過程で,
上部層では周辺地下水が流入するため抵抗変化がとらえ られて透水層を検出できる。しかし，時系列的な抵抗変 化は模式図のようになり，下部透水層を検出することが 困難である。一方，孔内微流速測定では流速測定によっ て，上部透水層での深さ方向への流速増加，下部透水層 に向かう流速一定区間の存在，下部透水層での流速低下 がとらえられ，透水層を検出することが出来る。このよ うに孔内微流速測定は孔内水の流動を可視化でき，透水 層を容易に検出することが出来るので広く普及させたい 孔内試験法である。

\section{5. 観測法の課題と展望}

\section{1 地表変動計測}

地盤伸縮計については，一般的な設置方法では積雪地 带での通年観測は積雪荷重の影響で困難であるが，イン バー線と保護管を埋設し，この点を解消したケースが見 受けられる。また，インバー線の替りに炭素繊維ケーブ ルを用いて凹凸のある地表に沿ってケーブルをフレキシ ブルに敷設し，地表の伸縮を計測する地盤伸縮計が開発 され，国土交通省新技術情報システム（NETIS）に登 録されている。更に，災害時における大変位に対応した 装置の開発も行われている（独立行政法人土木研究所ほ か, 2009)。

GPS観測については，原理上避けがたい測位誤差に対 して，統計処理により $\mathrm{mm}$ オーダの変位検知を可能にす るシステム（清水ほか，1998）や，基準点と観測点の標 高差に応じた受信機上空の水蒸気量の違いにより生じる 鉛直方向の見かけの変動を補正する手法（増成・清水, 2007 ; 中里ほか，2008）などが開発されている。今後準 天頂衛星の実用化やGPS信号の多周波数化などのインフ ラ整備により視界による制限の緩和や測位精度の向上が 期待される。

斜面の直接的な計測手段の中で，広域にモニタリング
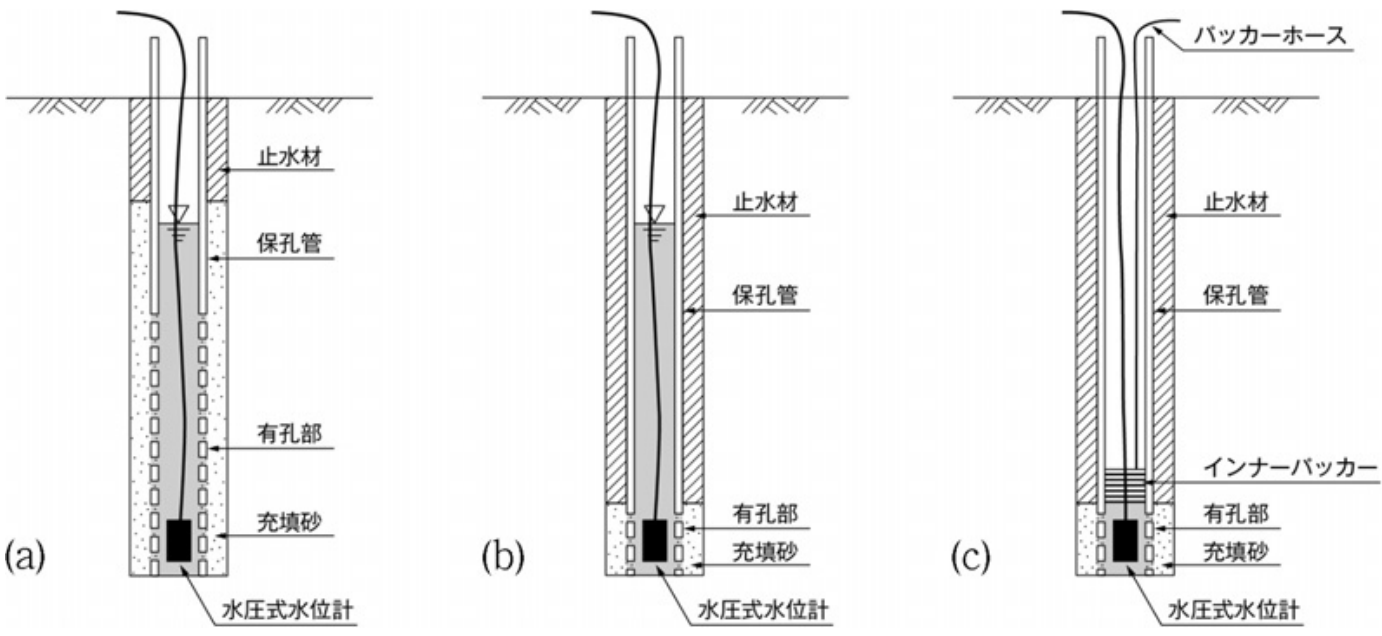

図一 4 水位測定孔の構造図

Fig. 4 Borehole structure of pore water pressure measurement 
可能な方法として光ファイバー自体をセンサ兼伝送路と して斜面へ設置する取り組みが研究されている（土木研 究所ほか, 2003)。現状では光ファイバーの斜面への設 置方法などに課題があるが，実用化の近い技術である。

非接触での地表変位計測手法としては，地上・空中写 真, 地上・空中から取得されたレーザ計測データ, 衛星 画像の時系列デー夕による計測と衛星SARがある。写 真撮影による計測は近年のデジタル画像処理技術の進歩 により近距離の対象を手軽に測定可能である。レーザ計 測は航空機から実施することを基本に考えると衛星画像 同様にデータの入手に時間を要する。干渉SARは，異 なる時期に地上の同一点に向けて航空機や人工衛星から 発射されたマイクロ波の反射波を観測し，発射源と地上 との距離の違いによる反射波の位相のずれを干渉画像と して表し， 2 時期間の地表面変位分布を面的にとらえる 技術である。特に衛星による干涉SARは広域的な情報 が得られ, 地震に伴う地表変動や大規模地すべり変動を とらえた事例が報告されている（宇根ほか，2008；鈴木 ほか，2010）。これらの成果の元となったLバンド合成 開口レーダを搭載する陸域観測技術衛星「だいち」は2011 年 5 月に運用を終了しており, 後継衛星の早期運用開始 が望まれる。これらの隔測的な時系列デー夕は, 地震等 による詳細な地表の変化を広域的にとらえることを可能 とするため, 広域災害時の初動調查や大規模地すべり認 定に打ける実用化段階の技術として今後の発展が期待さ れる。

\section{2 地中変動観測}

パイプひずみ計は耐用年数が 3 年程度であるため, 長 期間観測しているとパイプの曲がりが無い場合でも累積 的なひずみが発生することがある。長期観測になる場合 は孔内傾斜計の適用が望ましい。

パイプひずみ計の設置方式については，ひずみゲージ からのリード線をパイプ内に通して地上に出す内線式と リード線をパイプ外の孔壁との間に設置する外線式があ る。後者の場合, パイプをストレーナ加工して孔壁との 間を砂で充填し，パイプ内の孔内水位観測をあわせて行 うことが多い。孔内傾斜計測定も同様に孔内水位観測孔 との併用孔が見られる。合理的なようであるが地中変動 観測と孔内水位観測の双方の測定データの信頼性が低下 する。地中変動観測と孔内水位観測を別孔にすれば，パ イプひずみ計や孔内傾斜計の設置孔はグラウト充填によ る良質な観測孔とすることができる。後で述べる孔内水 位観測についても望ましい構造が採用できるため, 調査 費用は増加するが別孔測定で正確なデータを取得すべき である。

孔内傾斜計は温度の影響を受けやすいため，挿入式の 場合には孔内の温度になじませてから計測を開始しない と大きな誤差を生じる。この点に配慮しない観測，およ びガイドケーシングの設置が不十分な状態での観測など に起因して大きな誤差を含む測定結果が目立つように
なった。これらの結果は, 孔内傾斜計測定への不信感や 誤った判断に結びついている。このような状沉に鑑みて 独立行政法人土木研究所を中心に㨂入式孔内傾斜計に関 する計測マニュアル（2010）がまとめられ，良質なデー 夕の取得を目指す方向が示されたので，今後の観測に際 しては大いに参考にすべきである。

機器開発では，巻き上げ機を有する自動挿入式の孔内 傾斜計（計測ロボット）が開発され，頻繁な間隔での遠 隔測定が可能になった。また，安価なセンサーを用いた 孔内傾斜計の普及で, 孔内に 1 多数の設置式孔内傾斜 計を固定して連続的に遠隔測定を行うことも可能になっ た。事前にすべり面深度が確認されている場合に有効で あり，挿入式の孔内傾斜計測定を実施してすべり面を確 認した上で同じ測定孔を設置式に切り替えればよい。

地中変動の特殊な測定では, すべり面の破壊伝播の研 究（末峯, 2009）があり, 安価でデー夕処理が容易なパ イプひずみ計を密に設置 $(30 \mathrm{~cm}$ 間隔) して 2 分間隔で 自動観測を行っている。このような意欲的な研究への取 り組みが今後の機器開発にも影響を与えるものと思われ る。

また，複数のすべり面を有する地すべりではより浅層 のすべり面の活動により深層すべり面の長期的観測が行 えない場合がある。このような地すべりに対しては多層 移動量計が開発されているが，その適用深度は $50 \mathrm{~m}$ 程度 とされている。さらに深いすべり面に対しては，地中変 位や間隙水圧などのセンサデー夕を無線で地上に伝送し， 地すべり活動による断線の影響を受けないワイヤレスセ ンサが開発されており（農林水産省農村振興局農村政策 部農村環境課・農林水産省中国四国農政局農村計画部資 源課，2011)，これまで困難であった深層すべり面の挙 動解明への寄与が期待される。

\section{3 地下水観測}

地すべり機構の考察や排水対策を行う場合には，す心゙ り面に作用する間隙水圧の観測が必要であるが，厳密な 測定が扔ろそかにされている面がある。実務ではすべり 面の間隙水圧観測は簡便な孔内水位観測に置き換えられ ており，間隙水圧を正しく観測できている例は少ないと 思われる。すべり面の間隙水圧観測は地すべりの調査・ 観測分野において数十年間進歩無くもっとも遅れている 観測対象といえよう。

地すべり対策では排水対策が経済的であり，間隙水圧 観測が上手く出来れば効果的な排水対策につながる。こ のため，今後の調查・観測ではこれまでのような全長入 トレーナ加工の水位測定孔（図-4a）での測定にかわ り，できるだけ地下水検層や孔内微流速測定を実施して あらかじめ透水層を把握し, 透水層やすべり面に限定し て測れるように水位観測孔の構造を工夫して取り組むべ きである。透水区間を限定した観測孔は一般に図ー $4 \mathrm{~b}$ のような構造になるが，透水係数が小さいと正しい間隙 水圧は測定できない。榎田ほか（2009）は図－4 cに示 
す観測孔の構造を紹介しており大いに参考になる。学会 がこのような観測方法を積極的に提唱すべきであろう。

\section{6.おわりに}

大きな問題として, 調査では地すべり機構解明の基本 情報である地質図の作成が不十分であること，観測では すべり面の間隙水圧観測が孔内水位観測で置き換えられ て正しい間隙水圧観測ができない場合があるにも関わら ず数十年間にわたり実務レベルでの大きな進展がないこ とを強調しておきたい。

これらの技術的な課題への取り組みが実務面で求めら れる一方, 研究面では地震時の地すべり土塊の挙動を観 測機器によって明らかにすることが大きな問題として考 えられる。

今後はソフト対策として，観測機器によるモニタリン グが一層の重要視をされると思われる。とくに，地すべ り変位をある程度許容した性能設計の立場からのハード 対策が行われるようになれば，地すべり動態をモニタリ ングすることは必須の条件になる。

最後に，計測デー夕の収録システムに関することであ るが，初期の手動計測から測定デー夕の収録と処理の自 動化が進み，更には通信技術の発展によって現場に行か なくても測定データがリアルタイムで入手できるように なった。これは技術者の現場作業を軽減させた反面，現 場を観察する機会を少なくして状況把握が不十分になっ た。リアルタイムで現地の変位が把握できても斜面の変 動が大規模か局所的か，あるいは動植物の影響なのか判 断できないことがある。技術者の現場作業の割合が減つ たことは，調査機器を扱う機会が減ることにもなり，機 器に関する理解不足による取得デー夕の質の低下をもた らすことにつながった。このように，現場での調査や観 測の省力化が進む一方で顕在化する問題が出てきた。地 すべりを相手にする技術者は空調の利いた室内で机上の データで考察・判断するのではなく, デー夕を片手に積 極的に現場に飛び出して試行錯誤しつつ実態把握に努め 答えを出すべきである。新たな時代に向けて調査・観測 の基本を見直す必要がある。

\section{参考文献}

千葉達郎・冨田陽子・鈴木雄介・荒井健一 - 藤井紀綱 - 宮地直 道・小泉市朗・中島幸信 (2007)：航空レーザ計測にもとづく 青木が原溶岩の微地形解析, 富士火山, 山梨県環境科学研究 所, pp. 349-363.

独防災科学技術研究所（2011）：地すべり地形分布図データベース, http ://lsweb1.ess.bosai.go.jp/（参照日2011年11月30日）

独土木研究所ほか14社（2003）: 光ファイバセンサを活用した道路 斜面モニタリングシステムの導入・運用マニュアル (案)，共 同研究報告書，整理番号第292号.

独土木研究所・川崎地質株式会社・曙ブレーキ工業株式会社・坂 田電機株式会社・株式会社共和電業（2009）：厳しい条件下で の使用に耐えうる地すべり観測装置の開発, 共同研究報告書, 整理番号第393号.

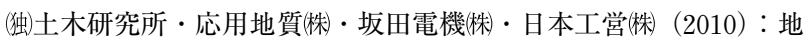
すべり地に抢ける挿入式孔内傾斜計計測マニュアル，理工図
書(侏).

榎田充哉・板山達至・土佐信一（2009）：地すべり観測機器の歴史 と現状， 6 . 地下水位計の歴史と現状，日本地すべり学会誌, Vol. 46, No. 4, pp. $48-54$.

榎田充哉・伴要 (2010)：地すべり観測機器の歴史と現状， 7 。地 下水検層器の歴史と現状, 日本地すべり学会誌, Vol. 47, No. 1, pp. $69-73$.

平元万晶 - 西窪文敏 - 中谷紀行 - 真弓孝之 ・ 神宮祐司 (2008)：地 中変位計で計測されるマイナス変位と移動土塊の変形，日本 地すべり学会誌, Vol.44, No.6, pp. 62-67.

福岡 浩 - 佐々恭二 ・平原和朗 - 島通保 - 日浦啓全 (1990)：人工 衛星測量（GPS）による地すべり移動観測，第29回地すべり 学会研究発表講演集, pp. $170-173$.

活断層研究会編（1980）：日本の活断層 分布図と資料，東京大学 出版会.

建設省国土地理院地理調査部（1976）：航空写真による崩壊調査法, 建設省国土地理院.

岸本良次郎（1967）：地すべり地に扔ける地下水・地表水（第三報）, 地すべり, Vol.3, No.3, pp. 21-39.

小林芳正・末峯 章・小西利史 (1979）：德島県正夫地すべり地に 打ける地震探査，地すべり，Vol. 15，No.4，20-27.

国土交通省国土政策局（2011）：GISホームページ国土情報ウエブ マッピングシステム，http://w3land.mlit.go.jp/（参照日2011 年11月30日)

向山栄（2010）：航空レーザ計測による地形の高精度判読，地盤工 学会誌, Vol. 58, No. 8, pp. 6-9.

中村浩之・板垣治（1976）：ストレインゲージパイプによるゲージ 間隔に対する考察，地すべり，Vol.13，No.2，pp. 21-26.

中村浩之・清水清文 (1978)：すべり面におけるセン断強度決定の ための土質試験法，地すべり，Vol.15，No.2，pp. 25-32.

中里裕臣・井上敬資 - 阿部栄一 - 高木圭介 - 増成友宏 - 武地美明 （2008）：GPSによる地すべり移動量観測における留意点，日 本地すべり学会誌, Vol.44, No.6, pp. 55-61.

中里裕臣 - 木下勝義 - 井上敬資 - 奥山武彦 - 須貝俊彦 - 八木浩司 （2009）：2009年 2 月25日以降の山形県鶴岡市七五三掛地す心゙ りの再活動と移動状況の特徵 (速報), 地学雑誌, Vol. 118, pp. $587-594$.

増成友宏・清水則一（2007）：GPSによる地盤変位計測における気 象の影響の補正方法の検討，土木学会論文集F，Vol.63， pp. $437-447$.

日本地すべり学会新潟支部（2008）：新潟県の地すべり災害と対策 の歴史, pp. $162-165$.

日本応用地質学会応用地形学研究小委員会 (2006)：応用地形七ミ ナー 空中写真判読演習，古今書院.

農林水産省農村振興局農村政策部農村環境課 - 農林水産省中国四 国農政局農村計画部資源課（2011）：ワイヤレス計器による地 すべり監視観測の新技術．地盤工学会誌，Vol. 59, No.9, pp. $42-43$.

大矢暁（1977）：高精度傾斜計の精度と適応性，応用地質，Vol. 18, No. $1 \cdot 2$, pp. $13-25$.

大八木規夫（1986）：I 斜面災害の歴史, 斜面災害の予知と防災, 白亜書房, p. 19 .

斎藤迪孝（1972）：斜面崩壊の予測について，土と基礎，Vol. 20, No. 2, pp. $13-19$.

斎藤迪孝（1976）：斜面と掘削，土と基礎，Vol. 24，No.8，pp. 33 -42 .

島裕雅・梶間和彦・神谷英樹・編（1995）：建設・防災・環境のた めの新しい電気探査法 比抵抗映像法, 古今書院.

社団法人地すべり対策技術協会（1996）：いつでも，どこでもすぐ に役立つ地すべり観測便覧，pp. 164-177.

清水文健・大八木規夫 ・井口隆（1982）：地すべり地形分布図第 1 集「新庄・酒田」.

清水則一・安立 寛・小山修治（1998）：GPS変位モニタリングシ ステムによる斜面変位計測結果の平滑化に関する研究，資源 素材学会誌, Vol.114,pp. 9-14.

Skempton, A.W.(1977) : Slope Stability of Cuttings in Brown London Clay, Proc. of 9th Int. Conf. of Soil Mechanics and 
Foundation Engineering, Vol. 3, pp. 261-270.

末峯章（2009）：地すべり観測機器の歴史と現状，4 ～パイプ歪計 の歴史と現状，日本地すべり学会誌，Vol.46，No.2，pp. 37 $-41$.

鈴木 啓・雨貝知美 - 森下 遊 - 佐藤 浩 - 小荒井 衛 - 関口辰 夫（2010）：山形県月山周辺におけるSAR干渉画像を用いた 地すべりの検出，国土地理院時報，No.120，pp.1-7.

鈴木隆司 · 内田太郎 - 田村圭司（2009）：深層崩壊発生斜面の特定 に向けた地盤構造調査法，土木技術資料，Vol. 51，No.7， pp. $8-13$.

田治米鏡二・岡田 広・浜田和郎・小柳敏郎 (1964)：井寒台で 行った地すべり調査のための予備的な比抵抗調査, 地すべり, Vol.1, No.2, pp. 5-7.

高野秀夫（1960）：地すべりと防止工法, 地球出版, pp. 67-103. 竹内篤雄 (1970)：電気探査より見た高知県下の破砕帯型地すべり 地について，地すべり，Vol.7, No.2, pp.19-30.

竹内篤雄（1996）: 温度測定による流動地下水調查法, 古今書院, $374-376$.

玉城逸夫・川本 整・藤田 崇・大場康行（1966）：亀の背地す心゙ りの研究 (2), 地すべり, Vol.2, No.3, pp. 5-11.

上野将司（2000）：地すべり地の地下水調査における微流速計の適
用，地すべり，Vol. 36，No.4, pp. 32-39.

宇根寛・佐藤浩・矢来博司・飛田幹男（2008）：SAR干渉画像を 用いた能登半島地震及び中越沖地震に伴う地表変動の解析, 日本地すべり学会誌, Vol.45, No.2, pp. 33-39.

渡正亮・酒井淳行（1965）：ボーリング孔を利用した地下水垂直探 査について, 地すべり, Vol.2, No.1, pp.1-9.

山田剛二・渡正亮・小橋澄治（1971）：地すべり斜面崩壊の実態と 対策，山海堂，pp. 247-250.

山田剛二・小橋澄治・草野国重（1971）：高場山トンネルの地すべ りによる崩壊，地すべり，Vol. 8, No.1, pp.11-24.

山口真一 $(1972)$ : パイプひずみ計により地すべり土塊の変形の姿 を求める方法について, 地すべり, Vol. 8, No.4, pp. 8-11.

山口真一 - 渡正亮 - 湊元光春 - 高田理夫 - 中村三郎 - 高田雄次 (1964)：地球物理学的調查法について, 地すべり, Vol. 1, No. 1 , pp. $35-44$.

山崎勉・山崎孝成・橋本純（2001）：地すべりにおけるBHTVの活 用，地すべり，Vol.38，No.1，pp.14-19.

横山俊治（2007）：地表地質踏査技術の伝承，地質と調查，2007年 3 号, pp. $19-22$.

（原稿受付2011年10月20日，原稿受理2011年12月 8 日） 